\title{
ADDRESS OF WELCOME
}

\author{
Rachel Laperrière \\ Bibliothèque municipale de Pointe-Claire, Montréal
}

Salutations :

Madame Claudia Lux, Présidente et directrice générale de l'IFLA;

Madame Roswitha Poll de l'ISO (Insternational Organization for Standardization), Ex-bibliothécaire en chef de la bibliothèque régionale et universitaire de Münster et chef du sous-comité 8 de l'ISO, Qualité - Statistiques et évaluation du rendement;

Monsieur Simon Ellis de l'Unesco-ISU (Institute for Statistics), Chef de la Section science, culture et communication, Institut de statistique (UNESCO);

Monsieur Michael Heaney de l'IFLA, Directeur général du Service des bibliothèques de l'Université d'Oxford (R.-U.)

Mesdames, Messieurs,

Bonjour,

Je tiens tout d'abord à vous souhaiter la bienvenue à Montréal. J'espère que les travaux que vous mènerez ici seront productifs, et qu'ils vous laisseront aussi quelques moments pour profiter de notre ville - si bien sûr vous n'avez pas oublié d'apporter un peu de beau temps dans vos bagages ...

L'histoire de nos bibliothèques publiques à Montréal n'a pas toujours été facile. Mais, au cours des dernières années, la communauté montréalaise a réalisé l'importance tout à fait centrale de ces institutions, dans une région qui compte de plus en plus sur l'économie du savoir et sur les compétences culturelles de sa population pour prendre sa place dans le réseau des grandes villes du monde.

For quite a long time, we in Montreal relied first and foremost on our exceptional location on this new continent to promote our economic growth and the metropolitan influence of our city. This wasn't a bad idea after all, as we succeeded in establishing a very dynamic commercial and industrial center where ocean liners coming from Europe met railroad networks that converged into our large inland port.

But this model met its limits, first with the economic transformation of North America, and second with the emergence of a radically different paradigm for the growth of the global economy. We came to realize that the main drive for our development, and for the quality of our urban life, depended more and more on the abilities of our people, rather than from mere geography and trading routes.

This realization has led to a genuine change of paradigm in the way we understand our city, assess its full potential, and draw our roadmap into the future.

Les grandes infrastructures qui ont donné son essor initial à Montréal ont admirablement réussi leur travail. Notre port, notre réseau ferroviaire et nos équipements de transbordement ont alimenté nos premières générations d'industries et 
ont fait de Montréal, pendant un certain temps, la grande métropole du Canada. Ils continuent toujours d'être le pivot de pans entiers de l'économie de Montréal et nous leur devons une part importante de notre prospérité économique.

Aujourd'hui, cependant, nous comprenons que la nouvelle économie a besoin d'une nouvelle génération d'infrastructures. Ces équipements et ces institutions ont une autre mission à remplir, d'autres défis à relever. Ils doivent agir d'abord et avant tout sur les connaissances, sur les compétences, sur la culture, sur la capacité d'apprendre et sur la créativité.

Ils doivent donner aux Montréalais et aux Montréalaises les outils et les habiletés pour réaliser leur plein potentiel dans une économie du savoir, dans une ville où la recherche scientifique, le développement technologique, la création culturelle et l'innovation en management ont maintenant pris la relève comme nouvelles locomotives de notre communauté.

Libraries are part of this new wave of knowledge-based infrastructures and institutions. Along with our schools, colleges and universities, also with our research centers and museums, as well as with our community organizations fighting against the modern social plague that is illiteracy, they are now an integral part of the very foundations of our "ville de savoir", of our "knowledge-based community".

This is why the Ville de Montréal, together with the government of Québec, have recently agreed to fund an ambitious program to build new public libraries, to modernize their equipments, and to expand their collections. Along with the recent inauguration of our new "Grande Bibliothèque", truly our first venture in this new generation of public libraries, these investments will radically change the face of our public library network in the next decade.

The huge popular success experienced by the Grande Bibliothèque since its opening, some five years ago, has made it clear that these investments gather a very large, across-the-board, support within the Montreal community.

Mais cet effort ne doit pas se limiter à l'ajout de bâtiments ou de mètres linéaires de rayons. Nous devrons compléter et enrichir nos collections, bien sûr, mais il faudra aussi, et surtout, revisiter le paradigme de base qui a présidé au développement des bibliothèques publiques, il $\mathrm{y}$ a maintenant un siècle et demi.

La quiétude des salles de lecture et l'ambiance silencieuse qui sont devenues les marques de commerce des bibliothèques, font écran au fait que ces institutions traversent une véritable révolution. Et il s'agit d'une révolution qui n'est pas tranquille du tout ...

Au cours des deux dernières décennies, nos bibliothèques ont vécu des transformations plus dramatiques que toutes celles - y compris l'invention du livre dans le format que nous lui connaissons aujourd'hui - qui ont marqué leur développement depuis la Bibliothèque d'Alexandrie, il y a 2300 ans.

Pour faire sa place en tant que ville de savoir, Montréal ne doit pas se contenter de rattraper la moyenne des autres villes canadiennes et de s'aligner sur des standards conventionnels. Montréal doit s'engager à fond dans la cette révolution en 
cours, une révolution qui se joue au moins autant dans l'espace virtuel et sur l'Internet que dans les salles de lecture et sur les rayons de documents.

Et cette révolution, elle devra compter en premier lieu sur notre créativité et sur nos innovations - ce dont nous ne manquons heureusement pas à Montréal - avant même d'aborder la question des budgets et des ressources.

This new paradigm of libraries - which translates into a new vision for the future of public libraries - has not yet evolved into a comprehensive model and a stable form: it remains a work-in-progress, a vision that has yet to fully materialize. This is not to say that the new library is something better to be left to future generations: it is already here. Now. Those who will not participate actively in the movement will be marked for obsolescence.

In Montréal, public libraries will have to bring specific contributions, not only to the civic and cultural life of the city, but to its economic and creative potential. The fact that these are very broad objectives does not prevent our libraries from being held accountable for their mission and for their actions.

This is why we have to rely on a comprehensive, reliable and meaningful set of data about our public libraries. This data must cover the libraries' internal administrative issues, from collection management to opening hours and service availability. But this data must also be relevant for deciders, who have to make decisions in a context where public resources remain scarce.

Public libraries will be judged according to their contribution to the social and economic development of the community they serve. Therefore, they will be expected to clearly demonstrate how, and to what extent, they can contribute to, and be accountable for, specific community goals like access to cultural material, improvement of literacy skills, support of adult self-learning, promotion of parental reading to their young children, integration of immigrants, use of second-language, graduation rate, employability, and more.

Voilà pourquoi vos discussions sur les statistiques des bibliothèques au $21^{\mathrm{e}}$ siècle revêtent une grande importance pour nous. Au moment où, à Montréal comme dans plusieurs autres villes comparables, nous nous engageons dans la mise en œuvre d'une nouvelle génération de bibliothèques, sans pour l'instant pouvoir en dessiner tous les contours, nous devons compter sur votre expertise pour tracer notre itinéraire, pour faire les bons choix, pour fixer les bonnes priorités.

Since 2004, the Ville de Montréal has been supported by the IFLA, especially by its the Standing Committee of the Statistics and Evaluation Section. With this support, during meetings in Buenos Aires, in Bergen, and in Capetown, we have been able to present and discuss the strategies and methods we have implemented so far.

In turn, those discussions and your support have brought us invaluable help in assessing our progress and in building our action plan. On behalf of the Ville de Montréal, I would like to express our sincere gratitude to IFLA in general, and especially to the Statistics and Evaluation Section. Thank you ... 
Vos travaux de ce congrès satellite, j'en suis sûre, vont pouvoir nous aider dans cette entreprise ambitieuse... et tout à fait enthousiasmante.

Je tiens à remercier les organisateurs, particulièrement Pierre Meunier et Céline Laperrière, de même que les participants à l'événement et vous souhaite un bon congrès.

Again, thank you, and have a very good stay in Montréal. 